\title{
A OUTRA
}

Erika Mayrink Vullu é mineira de Juiz de Fora, professora de língua portuguesa na faculdade Centro de Ensino Superior de Juiz de Fora. Mestre em Língua Portuguesa pela PUC-Rio, tem alguns textos publicados em sites, como releituras.com.

Email: emvullu@terra.com.br

De repente a mulher a viu. Assustou-se e recuou. Curiosa, espichou o pescoço e a procurou. Ela ainda estava lá. Imóvel. Presa.

Resolveu encará-la ainda que o medo a puxasse para longe dali. Olhou-a. Sentiu que a conhecia, mas a arrogância desviou a mulher da lembrança.

Os segundos andaram. Agora, a memória lhe dava tapas, mas ela persistia no olhar sem querer se lembrar.

Quis fugir dali como tantas vezes já fizera. Era assim que a mulher enfrentava o que não compreendia ou o que a assustava: corria e corria e corria até encontrar uma palavra que a confortasse internamente. Momentaneamente. Ilusoriamente.

Dessa vez, porém, ela não pôde fugir. Não tinha para onde ir. Não tinha palavras em que se abrigar. Estava só. Apenas ela e a outra.

Viu os cabelos negros brigando com a minoria branca; as pálpebras se rendendo à flacidez; os olhos castanhos escondendo o cansaço; a boca anunciando um grito (um sorriso?) que não veio.

As rugas. A mulher também as viu. Não eram muitas. Eram vivas e novas. Assustadoras e reveladoras. Cruéis e inexoráveis.

Talvez elas marcassem uma vida outrora jovem e vazia. Um viver displicente e presunçoso. Um caminhar incrédulo e altivo. Um ingênuo gosto de eternidade. Ou talvez marcassem uma juventude outrora feliz e completa. Um viver consciente e sereno. Um caminhar responsável e presente. Um amargo gosto de efemeridade.

E assim a mulher ficaria, conjeturando, inventando, enganando. Parece até que a outra alimentava suas invenções e a distanciava da verdade. Entretanto, a memória, cruel, novamente lhe esbofeteou a face.

Fechou os olhos e foi ali, na escuridão, que a verdade se aproximou. Abriu os olhos e se achou no banheiro de casa, o mármore frio da pia encostando na sua pele, a água da torneira molhando as mãos e o seu rosto refletido no espelho.

E então a mulher se viu. Viu aquelas rugas em si mesma. Era no seu rosto que elas estavam. Era a sua vida que elas projetavam. Era a sua juventude se perdendo num rosto que já não era mais seu. 